\title{
Penerapan Konsep Persamaan Diferensial Biasa Pada Pemodelan Tali Penahan Jembatan Gantung
}

\author{
Sri Wulandari Pratiwi ${ }^{1 *}$, Arjudin ${ }^{2}$, Nani Kurniati², Sripatmi $^{2}$
}

\author{
${ }_{1}^{1}$ Mahasiswa Pendidikan Matematika, FKIP, Universitas Mataram, Mataram \\ ${ }^{2}$ Dosen Pendidikan Matematika, FKIP, Universitas Mataram, Mataram \\ sriwulandaripratiwi@gmail.com
}

Diterima: 16-12-2021; Direvisi: 30-12-2021; Dipublikasi: 30-12-2021

\begin{abstract}
The purpose of this research to determine the form of capitalization of the suspension in the suspension bridge from the concept of ordinary differential equations and to determine solving differential equations and capitalizing suspension bridges, with suspension bridge in Gerung, West Lombok is a modelling. The type of this research is quantitative research with development methods literature. The subject in this research retaining ropes on suspension bridges. The data collected in the form of journals or articles from various related sources model of the retaining rope on a computed suspension bridge analyzed and concluded by the researcher through data analysis techniques by using the type of research triangulation principle and theoretical triangulation based on the results of data analysis, it was found that differential equations can be applied to modeling suspension bridges through first-order ordinary differential equations with the form of capitalization equations $\frac{d y}{d x}=\frac{W}{T_{1}}$ with the solution y $y=\frac{4 h}{L^{2}} x^{2}+a$, with the inteval in $\left[-\frac{L}{2} \leq x \leq \frac{L}{2}\right]$. The Gerung suspension bridge has its retaining rope modeling solution is $y=\frac{5}{1628} x^{2}+2,25$, in 12 right suspension at each hose $x_{n}=n \times 4,83$ in the interval $[-58 \leq x \leq 58]$ the related variable $y$ is the height of the retaining rope and $x$ the independent variable is the distance from the lowest restraint to the rope to be measured.
\end{abstract}

Keywords: ordinary differential equations; suspension bridge; ropes on suspension bridges

\begin{abstract}
Abstrak
Penelitian ini bertujuan untuk menentukan bentuk pemodelan tali penahan jembatan gantung dari konsep persamaan diferensial biasa serta untuk menentukan penyelesaian persamaan diferensial dari pemodelan tali penahan jembatan gantung, dengan jembatan gantung yang terletak di Gerung Lombok Barat sebagai contoh pemodelan. jenis penelitian ini adalah penelitian Kuantitatif dengan metode pengembangan literatur. Subjek dalam penelitian ini yaitu tali penahan pada jembatan gantung. Data dikumpulkan berupa jurnal atau artikel dari berbagai sumber terkait dengan model tali penahan pada jembatan gantung yang dikompulasi, dianalisis dan disimpulkan oleh peneliti melalui teknik analisis data dengan menggunakan jenis prinsip triangulasi peneliti dan triangulasi teoritis. Berdasarkan hasil analisis data diperoleh bahwa persamaan diferensial biasa dapat diterapkan pada pemodelan tali penahan jembatan gantung melalui persamaan diferensial biasa orde pertama dengan bentuk pemodelan persamaan $\frac{d y}{d x}=\frac{W}{T_{1}}$ dengan penyelesaiannya yaitu $y=\frac{4 h}{L^{2}} x^{2}+a$ pada rentang interval $\left[-\frac{L}{2} \leq x \leq \frac{L}{2}\right]$. Untuk model jembatan gantung Gerung memiliki penyelesain pemodelan tali penahannya yaitu $y=\frac{5}{1628} x^{2}+2,25$ dengan 12 tali penggantung kanan di setiap selang $x_{n}=n \times 4,83$ pada rentang interval [ $-58 \leq x \leq 58$ ] dengan $y$ variabel terikat adalah tinggi tali penahan dan $x$ varibel bebas adalah jarak dari tali penahan terendah ke tali penahan yang akan di ukur.
\end{abstract}

Kata Kunci: persamaan diferensial biasa; jembatan gantung; tali penahan 


\section{PENDAHULUAN}

Matematika merupakan salah satu cabang ilmu pengetahuan yang mendasari berbagai perkembangan ilmu pengetahuan, teknologi, dan seni modern (ipteks) serta mempunyai peranan penting dalam berbagai disiplin ilmu yang dikembangkan saat ini. Banyak cabang ilmu pengetahuan yang dikembangkan dari terapan matematika, sebagai contoh teori mandel pada biologi melalui konsep probabilitas,teori ekonomi melalui konsep fungsi, dan sebagainya (Fahrurrozi \& Hamdi, 2017).

Matematika itu bukan pengetahuan menyendiri dapat sempurna karena dirinya sendiri, tetapi adanya matematika untuk membantu manusia dalam memahami dan menguasai permasalahan sosial, ekonomi, dan alam (Isrok'atun et al., 2020). Turmuzi (2017) juga menyatakan bahwa matematika merupakan ilmu universal yang mendasari perkembangan teknologi modern, mempunyai peranan penting dalam berbagai disiplin ilmu dan mengembangkan daya pikir manusia. Dalam pendidikan, meningkatkan kualitas pembelajaran dengan mengintegrasikan teknologi merupakan hal yang penting untuk dilakukan (Salsabila \& Setyaningrum, 2019). Matematika banyak digunakan di berbagai disiplin ilmu, salah satu konsep matematika yang banyak digunakan dalam perkembangan ilmu pengetahuan ini adalah konsep persamaan diferensial lebih khususnya persamaan diferensial biasa.

Persamaan diferensial merupakan salah satu konsep dalam pembelajaran matematika yang banyak digunakan untuk menunjang berbabagi kebutuhan ilmu pengetahuan terapan lainnya melalui penggunaan konsep maupun cara perhitungannya, menurut Kreyszig (2011) persamaan diferensial biasa merupakan persamaan yang berisi satu atau beberapa turunan dari fungsi yang tidak diketahui, yang disebut $y(x)$ atau kadang $y(t)$ (jika variabel bebasnya adalah dalam waktu $t$ ) dimana persamaan ini mungkin juga dapat mengandung $y$ itu sendiri. Yang diketahui dalam persamaan ini berupa fungsi $x$ (ataut) dan konstanta.

Menurut Subandi (2019) persamaan diferensial biasa merupakan suatu turunan persamaan dari suatu fungsi yang didalamnya terdapat variabel bebas dan variabel terikat, baik satu atau lebih variabel. Jika hanya ada satu variabel bebas maka disebut dengan persamaan diferensial biasa, namun jika memiliki lebih dari satu variabel bebas maka bukan merupakan persamaan diferensial biasa melainkan merupakan persamaan diferensial jenis lain yaitu persamaan diferensial parsial. Sedangkan menurut Arjudin (2018) persamaan diferensial diartikan sebagai suatu persamaan yang mengandung turunan dari suatu fungsi atau biasa juga disebut dengan diferensial dari suatu variabel.

Persamaan diferensial biasa ini banyak diterapkan pada bidang-bidang ilmu pengetahuan lainnya seperti penggunaan persamaan diferensial biasa orde-2 pada sistem pegas masa Arjudin (2018), pada perhitungan temperatur, pertumbuhan dan peluruhan serta rangkaian RL (Sailah \& Cekdin, 2019). Terdapat pula penerapan persamaan diferensial biasa pada perhitungan di bidang ekonomi yaitu terkait dengan 
penambahan bunga tabungan pada bank (Pramudya, 2016). Aplikasi persamaan diferensial juga digunakan dalam mengestimasi jumlah penduduk dengan menggunakan metode eksponensial dan logistik (Rozikin et al., 2021). Pada mata kuliah fisika terdapat penerapan persamaan diferensial biasa yaitu aplikasi pada rangkaian $\mathrm{RL}$, aplikasi pada rangkaian $\mathrm{RC}$, aplikasi dalam peluruhan radioaktif, aplikasi dalam pertumbuhan populasi, aplikasi dalam hukum pendingan Newton, serta aplikasinya membahas persamaan dinamika satu dimensi yang dijumpai dalam sistem partikel bermassa yang terhubung dengan pegas (Gunada et al., 2017). Selain itu pada bidang teknik juga digunakan persamaan diferensial pada perhitungan geometri kurva kabel, perhitungan tegangan dan lainnya yang berkaitan dengan berbagai jenis jembatan (Nasution, 2009).

Karena persamaan diferensial dapat digunakan dalam perhitungan yang terkait dengan kurva atau kabel pada berbagai jenis jembatan maka peneliti tertarik untuk menggunakannya pada jenis jembatan gantung dimana jembatan gantung ini merupakan salah satu tipe jembatan bentang panjang yang dapat melintasi sungai sungai besar hingga menjadi penghubung antar pulau yang merupakan agenda kedepan yang direncanakan dalam pembangunan infrastruktur di Indonesia. Kebutuhan infrastruktur jembatan merupakan hal yang mutlak diperlukan guna menunjang roda perekonomian dan sosial budaya demi kemajuan suatu daerah (Setiati \& Wardhana, 2015). Jembatan gantung dipikul oleh kabel sebagai pemikul utama yang menumpu diatas 2 menara dan 2 pasang blok angkur (Munawir \& Nasution, 2017). Lebih detailnya jembatan gantung terdiri atas elemen utama mendasar: kabel utama, gelagar pengaku, menara dan blok angkur. Sistem kabel utama memikul beban terbagi rata simestris melalui bentuk parabolik klasik sehingga tidak terjadi defleksi, sedangkan fleksibel lentur akibat beban hidup asimetris dipikulkan pada gelagar pengaku (Tristanto et al., 2016). Pada jembatan gantung kabel/tali penahan merupakan bahan atau mateial utama dalam struktur jembatan gantung (Supriadi et al., 2019). Oleh karena itu penelitian ini menunjukkan penerapan persamaan diferensial biasa pada pemodelan tali penahan jembatan gantung.

\section{METODE PENELITIAN}

Jenis penelitian ini adalah penelitian kuantitatif dengan metode pengembangan literatur. Subjek dalam penelitian ini adalah tali penahan pada jembatan gantung dengan contoh pemodelan jembatan gantung yang digunakan yaitu pada jembatan gantung yang terletak di Gerung, Lombok Barat. Data alam penelitian ini digunakan buku maupun rujukan dan literatur yang terkait dengan persamaan diferensial maupun jembatan gantung yang dikumpulkan dari berbagai sumber pustaka untuk selanjutnya dikompulasi, dianalisis, dan disimpulkan sehingga mendapatkan kesimpulan.

Prosedur dalam penelitian ini meliputi tiga tahapan utama yaitu mengkaji yang meliputi mengkaji konsep persamaan diferensial, metode penyelesaian persamaan diferensial dan konteks jembatan gantung, kemudian tahapan kedua yaitu 
mengembangkan yang meliputi mengembangkan pemodelan jembatan gantung dan metode penyelesaian pada pemodelan tali penahan jembatan gantung serta tahapan kterakhir yaitu merapkan hasil pengembangan dan pengkajian melalui penyelesaian kasus atau contoh masalah terkait dengan tali penahan pada jembatan gantung.

Pada teknik analisis data menggunakan prinsip triangulasi yaitu merupakan prinsip analisis atau menguji keabsahan data yang berbeda sampai data yang telah diambil jenuh, sehingga dapat diambil sintesis data yang absah atau valid. Prinsip triangulasi memiliki empat jenis yaitu triangulasi data, triangulasi peneliti, triangulasi metode dan triangulasi teoritis (Sahide, 2019). Dalam penelitian ini menggunakan prinsip triangulasi peneliti dan triangulasi teoritis dikarenakan pada triangulasi peneliti menguji menguji sudut pandang peneliti dalam memandang data, mentranskip data, serta mengambil tindakan terhadap objek data. Serta triangulasi teoritis digunakan hasil akhir dari penelitian ini yaitu merupakan suatu informasi yang sebelumnya telah dibandingkan dengan berbagai teori yang relevan. Hal ini menjadi penting dikarenakan poin penting dalam sebuah penelitian ilmiah adalah originalitas atau sifat keasliannya (Sugiarti, Andalas \& Setiawan, 2020).

\section{HASIL DAN PEMBAHASAN}

Berdasarkan prosedur penelitian yang dilakukan maka hasil dari penelitian ini meliputi tiga proses/tahapan utama yaitu:

\subsection{Hasil Penelitian Dari Proses Pengkajian}

Dari proses pengkajian didapatkan bahwa sistem kerja jembatan gantung memiliki kesamaan dengan sistem kerja pada tempat tidur gantung dimana terdapat 3 gaya utama yang bekerja pada jembatan gantung yaitu dua gaya tegangan dan sebuah gaya beban dan diilustrasika seperti pada gambar berikut
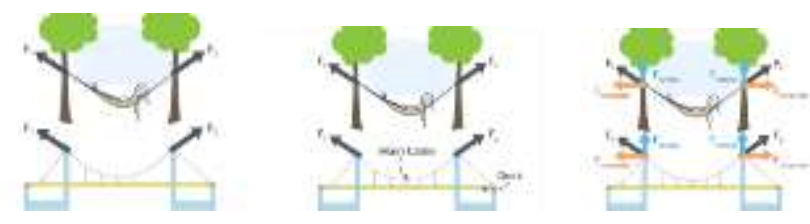

Gambar 1 Sistem Kerja Jembatan Gantung Mirip Dengan Sistem Pada Tempat Tidur Gantung

\subsection{Hasil Penelitian Dari Proses Pengembangan}

Dari proses pengembangan diperoleh:

Dimana:

$$
\frac{d y}{d x}=\frac{W}{T_{1}}
$$

$W=$ Beban yang bekerja pada jembatan gantung

$T_{1}=$ Tegangan di salah satu titik pata kabel utama 
$x=$ Variabel bebas yaitu jarak tali penahan terendah ke tali penahan yang di ukur

$y=$ Variabel terikat yaitu tinggi tali penahan

Merupakan suatu bentuk persamaan diferensial biasa orde pertama yang digunakan dalam memodelkan tali penahan pada jembatan gantung fleksibel.

Karena dalam penelitian ini menggunakan jembatan gantung kaku maka penyelesaian untuk jembatan kaku menggunakan persamaan diatas yang telah dikembangkan menghasilkan

Dimana:

$$
y=\frac{4 h}{L^{2}} x^{2}+a
$$

$h=$ Tinggi kemiringan pada jembatan

$L=$ Panjang jembatan

$a=$ Tinggi tali penahan terendah pada jembatan gantung

dan merupakan penyelesainnya persamaan diferensial dari pemodelan jembatan gantung pada selang interval $\left[-\frac{L}{2} \leq x \leq \frac{L}{2}\right]$

\subsection{Hasil Penelitian Dari Proses Penerapan}

Dari proses penerapan yang dilakukan pada jembatan gantung Gerung dengan data sebagai berikut

Tabel 1. Data jembatan gantung Gerung.

\begin{tabular}{lc}
\hline \multicolumn{1}{c}{ Nama satuan yang diukur } & Hasil (Meter) \\
\hline Panjang Jembatan $(L)$ & 116 \\
Tinggi kabel terendah pada tali penggantung $(a)$ & 2,25 \\
Tinggi total jembatan (diukur dari badan jalan yang ada & 12,25 \\
pada jembatan) & 10 \\
Tinggi kemiringan pada jembatan gantung $(h)$ & 4,83 \\
Jarak pada setiap selang tali penahan $(x)$ & \\
\hline
\end{tabular}

Diperoleh bahwa penyelesaian persamaan diferensial untuk jembatan gantung gerung adalah

$$
\begin{aligned}
& y=\frac{4(10)}{116^{2}} x^{2}+2,25 \\
& y=\frac{5}{1628} x^{2}+2,25
\end{aligned}
$$

Untuk memperoleh model tali penahan pada jembatan gantung gerung maka perlu diketahui bahwa jembatan gantung Gerung memiliki 25 tali penahan yang berada pada interval [ $-58 \leq x \leq 58$ ] serta jarak pada setiap tali penahannya adalah 4,83 (satuan panjang) dengan masing-masing 12 tali penahan pada sisi kanan dan kiri serta satu tali penahan terendah yang di simbolkan dengan $x_{0}$ dan tinggi kabel terendah tersebut adalah $y_{0}$ atau $a$. Sehingga menggunakan data yang ada diperoleh $y$ atau tinggi pada setiap tali penahan disajikan dalam tabel berikut: 
Tabel 2. Data Nilai Tinggi Tali Penahan Jembatan Gantung Gerung

\begin{tabular}{|c|c|c|c|}
\hline$x_{n}$ & $\begin{array}{l}\text { Nilai } x \\
\text { (meter) }\end{array}$ & $\begin{array}{l}y=\frac{5}{1628} x^{2}+ \\
2,25 \text { (meter) }\end{array}$ & Titik Koordinat $(x, y)$ \\
\hline$x_{0}$ & 0 & 2,25 & $(0,(2,25))$ \\
\hline$x_{1}$ & 4,83 & 2,32165 & $((4,83),(2,32165))$ \\
\hline$x_{2}$ & 9,66 & 2,5366 & $((9,66),(2,5366))$ \\
\hline$x_{3}$ & 14,49 & 2,89484 & $((14,49),(2,89484))$ \\
\hline$x_{4}$ & 19,32 & 3,39638 & $((19,32),(3,389638))$ \\
\hline$x_{5}$ & 24,15 & 4,04122 & $((24,15),(4,04122))$ \\
\hline$x_{6}$ & 28,98 & 4,82936 & $((29,98),(4,82936))$ \\
\hline$x_{7}$ & 33,81 & 5,7608 & $((34,81),(5,7608))$ \\
\hline$x_{8}$ & 38,64 & 6,83553 & $((39,64),(6,83553))$ \\
\hline$x_{9}$ & 43,47 & 8,05357 & $((43,47),(8,05357))$ \\
\hline$x_{10}$ & 48,3 & 9,4149 & $((48,3),(9,4149)$ \\
\hline$x_{11}$ & 53,13 & 10,91952 & $((53,713),(10,91952)$ \\
\hline$x_{12}$ & 57,96 & 12,56745 & $((57,96),(12,56745))$ \\
\hline$x_{-1}$ & $-4,83$ & 2,32165 & $((-4,83),(2,32165))$ \\
\hline$x_{-2}$ & $-9,66$ & 2,5366 & $((-9,66),(2,5366))$ \\
\hline$x_{-3}$ & $-14,49$ & 2,89484 & $((-14,49),(2,89484))$ \\
\hline$x_{-4}$ & $-19,32$ & 3,39638 & $((-19,32),(3,389638))$ \\
\hline$x_{-5}$ & $-24,15$ & 4,04122 & $((-24,15),(4,04122))$ \\
\hline$x_{-6}$ & $-28,98$ & 4,82936 & $((-29,98),(4,82936))$ \\
\hline$x_{-7}$ & $-33,81$ & 5,7608 & $((-34,81),(5,7608))$ \\
\hline$x_{-8}$ & $-38,64$ & 6,83553 & $((-39,64),(6,83553))$ \\
\hline$x_{-9}$ & $-43,47$ & 8,05357 & $((-43,47),(8,05357))$ \\
\hline$x_{-10}$ & $-48,3$ & 9,4149 & $((-48,3),(9,4149)$ \\
\hline$x_{-11}$ & $-53,13$ & 10,91952 & $((-53,713),(10,91952)$ \\
\hline$x_{-12}$ & $-57,96$ & 12,56745 & $((-57,96),(12,56745))$ \\
\hline
\end{tabular}

Keterangan: $x_{n}$ merupakan tali penahan jembatan gantung sebelah kanan dari $x_{0}$ dan $x_{-n}$ merupakan tali penahan jembatan gantung sebelah kiri dari $x_{0}$ dengan $n=1 \ldots 12$. Untuk mencari nilai $x_{n}$ atau $x_{-n}$ yaitu dengan

$$
x_{n}=n \times 4,83 \text { atau } x_{-n}=-n \times 4,83
$$

Dari tabel tersebut diperoleh gambar atau ilustrasi dari model tali penahan pada jembatan gantung Gerung adalah sebagai berikut:

Jembatan Gantung pada mulanya diciptakan dari pendekatan suatu jembatan balok dan jembatan lengkung. Jembatan gantung telah digunakan sejak dahulu, dimana jembatan gantung tertua dan terbesar dibangun pada abad ke-18 yang bernama jembatan Menai Straits di Inggris yang dibangun pada tahun 1825 (Munawir \& Nasution, 2017). Pada pengembangannya, untuk mempermudah dalam pengilustrasian suatu jembatan gantung maka digunakanlah ilustrasi yang sama dengan cara kerja pada suatu tempat tidur gantung (hammock). 


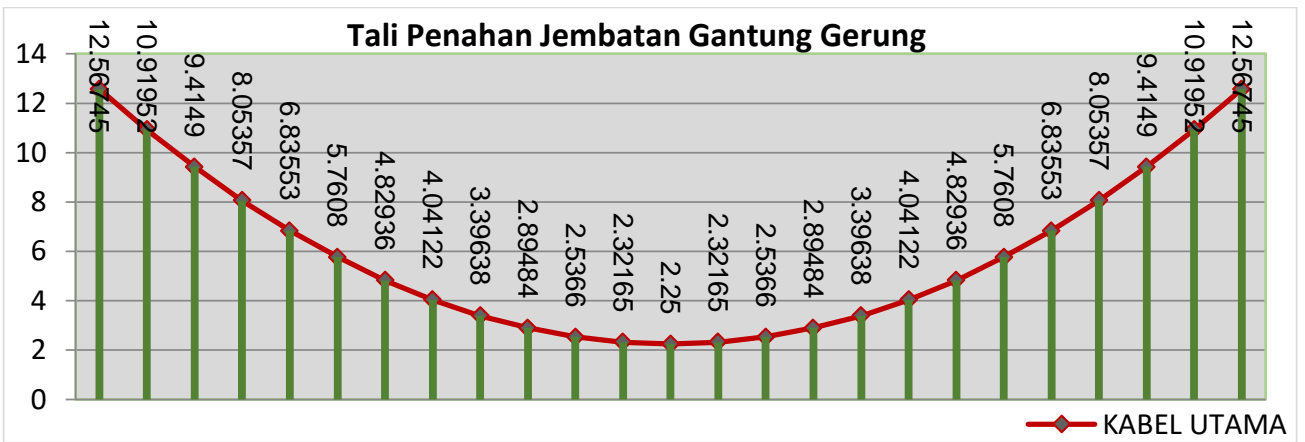

Gambar 2 Ilustrasi Jembatan Gantung Gerung

Pada model tempat tidur gantung (Gambar 1) terdapat 3 gaya utama yang bekerja yaitu $T_{1} \& T_{2}$ sebagai gaya tegangan pada kedua tali pendukungnya, serta $W$ merupakan beban yang bekerja, hal tersebut juga berlaku pada jembatan gantung dimana jembatan gantung juga memiliki 3 gaya utama seperti tempat tidur gantung.

Pada proses pengembangannya, kabel utama pada jembatan gantung jika diambil pada salah satu bagian misalnya pada bagian kanan seperti pada gambar berikut

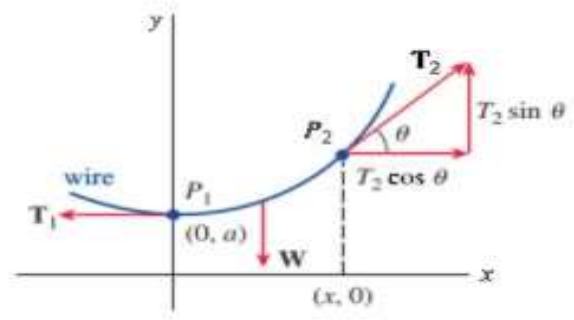

\section{Gambar 3 Bagian Kabel Utama Jembatan Gantung}

Keterangan :

$P_{1}=$ Titik terendah pada kabel

$P_{2}=$ Titik sebarang pada kabel

$T_{1}=$ Tegangan yang bersinggungan dengan $P_{1}$

$T_{2}=$ Tegangan yang bersinggungan dengan $P_{2}$

$W=$ Beban Vertikal total antara $P_{1} \& P_{2}$

Maka dari bagian kabel tersebut dimisalkan $T_{1}=\left|T_{1}\right|, T_{2}=\left|T_{2}\right|$, dan $W=|W|$ yaitu vektor dari gaya-gaya tersebut, $T_{2} \cos \theta$ merupakan Tegangan horizontal $T_{2}$ kemudian $T_{2} \sin \theta$ merupakan Tegangan Vertikal $T_{2} \operatorname{serta} \theta$ merupakan besarnya sudut pada $P_{2}$. Perlu diketahui bahwa $T_{2} \cos \theta$ dan $T_{2} \sin \theta$ merupakan suatu kesetimbangan statis, maka diperoleh $T_{1}=T_{2} \cos \theta$ dan $W=T_{2} \sin \theta$ sehingga

$$
\frac{W}{T_{1}}=\frac{T_{2} \sin \theta}{T_{2} \cos \theta}=\frac{\sin \theta}{\cos \theta}=\tan \theta=\frac{d y}{d x}
$$

Hal tersebut akan sama artinya dengan 


$$
\frac{d y}{d x}=\frac{W}{T_{1}}
$$

Sehingga persamaan tersebut merupakan persamaan diferensial orde pertama untuk jembatan gantung fleksibel (Zill \& Warren S. Wright., 2014). Perlu diketahui bahwa Persamaan diferensial biasa orde satu dapat diklasifikasikan dalam beberapa bentuk persamaan, yaitu persamaan linier, persamaan Bernoulli, persamaan homogen, persamaan yang dapat dipisahkan, dan persamaan eksak serta faktor integrasi (Ibnas, 2017). Kemudian, karena dalam penelitian ini digunakan jembatan gantung Gerung sebagai contoh model yang dimana jembatan gantung Gerung merupakan tipe jembatan Gantung kaku sehingga untuk mencari penyelesaian persamaan diferensial dari jembatan gantung kaku maka ditetapkan berat per satuan panjang badan jalan adalah konstan atau tidak berubah meski ada perbedaan pembebanan, kemudian hal tersebut diberi simbol $\rho$ maka

Sehingga

$$
W=\rho x
$$

$$
\frac{d y}{d x}=\frac{\rho x}{T_{1}}
$$

Persamaan tersebut diatas kemudian Diselesaikan dengan metode terpisahkan pada persamaan diferensial sehingga menghasilkan

$$
\begin{gathered}
d y=\frac{\rho x}{T_{1}} d x \\
\int d y=\int \frac{\rho x}{T_{1}} d x
\end{gathered}
$$

Sehingga solusi umum persamaan diferensial biasa untuk model tali penahan jembatan gantung kaku diperoleh dengan

$$
y=\frac{\rho}{2 T_{1}} x^{2}+C
$$

Pada suatu kondisi dimana sumbu $Y$ merupakan tali penahan terendah memungkinakan untuk diperoleh titik terendahnya adalah $(0, a)$ maka $y(0)=a$ sehingga jika disubstitusikan kembali pada solusi umum pada model tali penahan jembatan gantung sebelumnya didapatkan $C=a$, sehingga solusi tersebut dapat dituliskan ulang sebagai persamaan berikut:

$$
y=\frac{\rho}{2 T_{1}} x^{2}+a
$$

Tetapi pada suatu jembatan gantung (Gambar 4) terdapat tinggi suatu kemiringan $h$ yang didapat dihitung dengan tinggi total jembatan (tinggi tali penahan paling tinggi) dikurangi tinggi tali penahan terendah. Serta $L$ yang merupakan panjang rentang jembatan 


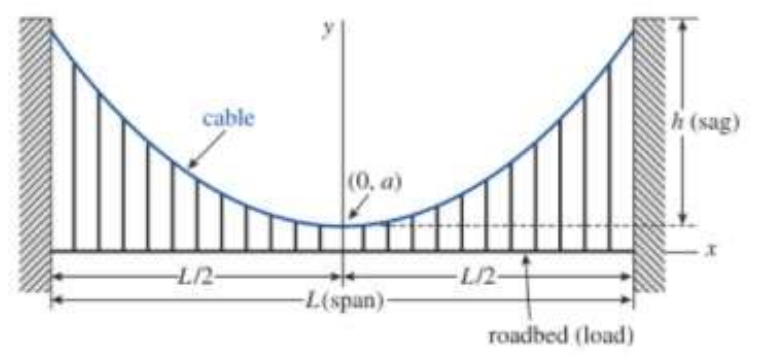

Gambar 4 Jembatan Gantung Kaku

Maka dengan mengambil $\frac{L}{2}$ (jumlah panjang jembatan dari titik 0 sampai $\frac{L}{2}$ ) pada rentang $\left[-\frac{L}{2}, \frac{L}{2}\right]$. Maka tinggi lengkung untuk lengkung kabel tertinggi $\frac{L}{2}$ akan menjadi $a+h$ sehingga dapat dituliskan:

$$
y\left(\frac{L}{2}\right)=a+h
$$

Kemudian kita substitusikan $y\left(\frac{L}{2}\right)=a+h$ pada $y=\frac{\rho}{2 T_{1}} x^{2}+a$ maka akan di dapatkan

$$
\begin{aligned}
& a+h=\frac{\rho}{2 T_{1}}\left(\frac{L}{2}\right)^{2}+a \\
& h=\frac{\rho}{2 T_{1}}\left(\frac{L}{2}\right)^{2}+a-a \\
& h=\frac{\rho}{2 T_{1}}\left(\frac{L^{2}}{4}\right) \\
& \frac{\rho}{2 T_{1}}=\frac{4 h}{L^{2}}
\end{aligned}
$$

Setelah itu persmaan $\frac{\rho}{2 T_{1}}=\frac{4 h}{L^{2}}$ disubstitusikan kembali ke persamaan awal yaitu $y=$ $\frac{\rho}{2 T_{1}} x^{2}+a$ sehingga diperoleh penyelesaian persamaan diferesial biasa untuk jembatan kaku dengan diketahui nilai $L, h$, dan $a$ adalah

$$
y=\frac{4 h}{L^{2}} x^{2}+a
$$

Untuk jembatan gantung Gerung dengan nilai $h=10$ meter, $L=116$ meter dan $a=2,25$ meter diperoleh bentuk penyelesaian persamaan diferensialnya adalah

$$
y=\frac{5}{1628} x^{2}+2,25
$$

Jarak antara setiap kabel penggantung adalah sama yaitu 4,83 meter Nilai $x$ yang menjadi variable bebas diperoleh dengan cara $x_{n}=4,83 \times n$ atau $x_{n}=x_{n-1}+4,83$. Dimana $n$ merupakan tali yang akan di cari nilainya misalnya $n=4$ maka akan berarti tali ke empat setelah tali terpendek. tali penahan terpendek disimbolkan dengan $x_{0}$. Maka penyelesaian persamaan diferensial biasa untuk mencari tinggi tali penahan pada jembatan gantung gerung akan sama dengan

$$
\begin{gathered}
y_{n}=\frac{5}{1628} x_{n}{ }^{2}+2,25 \\
y_{n}=\frac{5}{1628}(4,83 \times n)^{2}+2,25
\end{gathered}
$$


Dari titik-titk koordinat yang diperoleh pada tabel 2 dapat diilustrasikan kembali sehingga menghasilkan model jembatan gantung gantung Gerung seperti pada gambar 2 .

\section{SIMPULAN}

Berdasarkan tujuan penelitian ini maka dapat disimpulkan bahwa:

a. Bentuk pemodelan tali penahan jembatan gantung dapat ditentukan dengan konsep persamaan diferensial biasa orde pertama melalui persamaan

Dimana

$$
\frac{d y}{d x}=\frac{W}{T_{1}}
$$

$W=$ Beban yang bekerja pada jembatan gantung

$T_{1}=$ Tegangan di alah satu titik pada kabel utama (main cable)

$x=$ Variabel bebas yaitu jarak tali penahan terendah ke tali penahan yang diukur

$y=$ variabel terikat yaitu tinggi tali penahan

b. Dalam menentukan penyelesaian persamaan diferensial pada model persamaan diferensial biasa diatas dapat ditentukan dengan pengembangan melalu jembatan gantung kaku dengan interval jembatan $\left[-\frac{L}{2} \leq x \leq \frac{L}{2}\right]$ maka didapatkan bentuk penyelesainnya persamaan diferensial biasa dari pemodelan jembatan gantung tersebut yaitu :

Dimana

$$
y=\frac{4 h}{L^{2}} x^{2}+a
$$

$h=$ tinggi kemiringan pada jembatan

$L=$ panjang jembatan

$a=$ Tinggi terendah pada kabel penggantung jembatan gantung.

Untuk penerapan konsep persamaan diferensial biasa pada pemodelan tali penahan jembatan gantung dengan model tali penahan pada jembatan gantung Gerung dengan $h=10, L=116$, dan $a=2,25$ didapatkan penyelesaian persamaan diferensialnya adalah:

$$
y=\frac{5}{1628} x^{2}+2,25
$$

\section{REFERENSI}

Arjudin. (2018). Persamaan Diferensial. Universitas Mataram.

Fahrurrozi, \& Hamdi, S. (2017). Metode Pembelajaran Matematika. Universitas Hamzanwadi.

Gunada, I. W., Rokhmat, J., Hikmawati, H., \& Kesipudin, K. (2017). Pengembangan Bahan Ajar Kompilasi Fisika Matematika Ii Pokok Bahasan Persamaaan Diferensial Untuk Meningkatkan Penalaran Matematis. Jurnal Pendidikan Fisika Dan Teknologi, 3(2), 216. https://doi.org/10.29303/jpft.v3i2.414

Ibnas, R. (2017). Persamaan Differensial Eksak Dengan Faktor Integrasi. JURNAL MSA, 5(2), 
68-80.

Isrok'atun, H. N., Maulana, \& Suhaebar, I. (2020). Pembelajaran Matematika dan Sains secara Integratif melalui Situation-Based Learning. UPI Sumedang Press.

Kreyszig, E. (2011). Advance Engineering Mathematics (Tenth Edit). John Wiley \& Sons, Inc.

Munawir, \& Nasution, N. C. (2017). Pengaruh Suspender Tipe Vertical Dan Inclined Terhadap. $3(2), 13-22$.

Nasution, A. (2009). Metode Matrik Kelakuan Analisis Struktur. ITB.

Pramudya, G. (2016). Introduction to Differential Equations. In Jurnal Research. https://doi.org/10.13140/RG.2.1.3038.1688

Rozikin, N., Sarjana, K., Arjudin, A., \& Hikmah, N. (2021). Aplikasi Persamaan Diferensial Dalam Mengestimasi Jumlah Penduduk dengan Menggunakan Model Eksponensial dan Logistik. Griya Journal of Mathematics Education and Application, 1(1), 44-55. https://doi.org/10.29303/griya.v1i1.7

Sahide, M. A. K. (2019). Buku Ajar Metodologi Penelitian Sosial: Keahlian Minimum Untuk Teknik Penulisan Ilmiah. Fakultas Kehutanan Unversitas Hasanuddin.

Sailah, S., \& Cekdin. (2019). Persamaan Diferensial Pendekatan Praktis. Andi.

Salsabila, N. H., \& Setyaningrum, W. (2019). Pengembangan Media Pembelajaran Matematika Berbasis Game: Statistics In Arctic. MANDALIKA Mathematics and Educations Journal, 1(1), 13. https://doi.org/10.29303/jm.v1i1.1248

Setiati, N. R., \& Wardhana, P. K. (2015). Kekuatan Struktur Jembatan Gantung Sederhana Untuk Pejalan Kaki. Jurnal HPJI, 1(2), 67-76.

Subandi, A. (2019). Aljabar Dan Kalkulus. Rekayasa Sains.

Sugiarti, Andalas, E. ., \& Setiawan, A. (2020). Desain Penelitian Kualitatif Sastra. UMMPress.

Supriadi, S., Susilawati, S., \& Tristyanto, B. (2019). Ethnomathematics in Mathematics, Social and Physical Education. Journal of Physics: Conference Series, 1318(012126). https://doi.org/10.1088/1742-6596/1318/1/012126

Tristanto, L., Sukmara, G., \& Nasution, J. A. H. (2016). Struktural ( Modification Of Main Cable System Of Suspension Bridges By Clamp To Increase Structural Stiffness ) di Kalimantan Selatan yang merupakan diketemukan dan sekarang sistem klem lazim digunakan. 43-56.

Turmuzi, M. (2017). Strategi Pembelajaran Matematika. Fakultas Keguruan dan Ilmu Pendidikan Universitas Mataram.

Zill, D. G., \& Warren S. Wright. (2014). Advance Engineering Mathematics, Fifth Edition. Courier Companie. 